\title{
延性金属の一様ひずみに及ぼす降温プロセスの影響
}

\author{
上村 岳之* . 大澤 泰明*
}

\begin{abstract}
Journal of The Japan Institute of Light Metals, Vol. 63, No. 12 (2013), 439-445
\end{abstract}
(c) 2013 The Japan Institute of Light Metals

\section{Effect of temperature descent process on uniform strain of ductile metals}

\author{
Takayuki UEMURA* and Hiroaki OHSAWA*
}

\begin{abstract}
An analysis on plastic instability theory together with some constitutive equations involving strain, strain rate and temperature leads to simple conclusion, which suggests an increase of uniform strain range by falling off temperature intentionally during the process. To evaluate the above prediction, the concept of temperature descent is provided and the usefulness of cooling down with the process temperature is shown by the comparison with constant temperature. Experiments were carried out in uniaxial tensile test, methods of cooling with using natural cooling and air blow cooling. It was observed that temperature descent during forming process causes a significant rise of the uniform strain. In the case of air blow cooling, significant increase of uniform strain was seen because temperature descent rate was larger than natural cooling. The result may be applied to any other metal, being independent of metal class, thus generalized concept seems to be reached to extension in uniform strain range of metals with poor formability.
\end{abstract}

(Received February 27, 2013 Accepted July 28, 2013)

Keywords: plastic instability, constitutive equation, uniform strain, temperature descent, high temperature deformation

\section{1. 緒言}

アルミニウム, マグネシウム, チタン合金などの非鉄軽量 金属に対する期待が医療福祉 ${ }^{1)}$, 輸送機器関連分野 ${ }^{2)}$ を中心 に高まっており, 需要の増加や用途の拡大が顕著に認められ $3^{3), 4)}$ 。板材のプレス加工分野においてこれら金属板材は一 般的に難加工性材料に分類され，鉄鋼材に比して成形性は確 実に劣るものと認識されていて，マグネシウム合金薄板の箱 型製品の例では薄板からのプレス加工によらず, 生産効率を 度外視して半凝固鋳造法が活用されている3）。

劣悪な成形性の要因は, それぞれの材料や合金に応じて 様々であるが，結晶構造のすべり系，およびその数の大小に 負うところが大きく，これらによって難加工性が端的に説明 されている ${ }^{5)}$ 。高温では室温において休止していたすべり系 が活性化してくるので, 加工性を向上させる一般的な方策と して加工温度を高く設定することが挙げられる ${ }^{5)}$ 。板材の深 絞りや張出に属する加工では，一様かつ定常な温度場が通常 は前提とされる。周辺加熱染絞りでは, ブランクの周辺部 は高温, 中心部は低温を保つ非一様な温度場が利用される。 しかしながら, これら高温加工において加工温度場の一様/ 非一様あるいは定常/非定常に言及した詳細な実験研究は質, 量とも極めて限定されている。

本研究では, $\mathrm{Zn}-\mathrm{Al}$ 共析組成合金（SPZ）およびAZ31マグ ネシウム合金を対象にして, 変形中に試験体の周辺温度を意
識的に降下させること（降温プロセス）により安定な変形能 が増大することを予測する解析結果 ${ }^{6)}$ を提示し, その上で 引張試験における一様ひずみが実際にこの手法により向上す

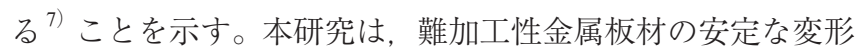
能を向上させる普遍的な方法として, 降温プロセスの重要性 と可能性を実験解析により明示することが目的である。

\section{2. 一様ひずみの解析予測}

扱う材料は均質，等方で，高温に曝されている間に生じる 再結晶などの金属組織変化は考慮せず弾性変形も無視する。 ひずみ, ひずみ速度, 温度を独立変数とし, 流動応力をそれ らの関数として（1）式タイプの構成方程式を考える。

$$
\sigma=\sigma(\varepsilon, \dot{\varepsilon}, T)
$$

おそらく，(2)式の構成式は（1)式のタイプの中で最もよく 引用されるものであろう ${ }^{8)}$ 。

$$
\sigma=K \dot{\varepsilon}^{m} \varepsilon^{n} \exp \left(\frac{A}{T}\right)
$$

ここで, 材料特性值 $K$ は $\varepsilon=\dot{\varepsilon}=1$ かつ $T=\infty$ の とき応力值であ り, $m, n, A$ はおのおの塑性変形の流動応力に関するひずみ 速度, ひずみ, 温度依存性の定量化数值であり, 次のように 定義される。

\footnotetext{
*法政大学 理工学部 機械工学科（†184-8584 東京都小金井市梶野町 3-7-2)。Department of Mechanical Engineering, Hosei University (3-7-2 Kajino-cho, Koganei-shi, Tokyo 184-8584).E-mail: takayuki.uemura.33@adm.hosei.ac.jp
} 


$$
m=\frac{\partial \ln \sigma}{\partial \ln \dot{\varepsilon}}, \quad n=\frac{\partial \ln \sigma}{\partial \ln \varepsilon}, \quad A=\frac{\partial \ln \sigma}{\partial(1 / T)}
$$

いずれも，偏微分に基づく定義式であり，常微分による定義 とは物理的意味が異なることに注意する。一般的に材料特性 值 $K, m, n, A$ は, 実験内で想定されるひずみ, ひずみ速度, 温度のある範囲内で一定值として扱われる。

延性金属の引張試験における最高荷重点までの公称ひずみ は一様伸びと呼ばれ，その大きさは安定変形の尺度となる。 本論文においては最高荷重点までのひずみを一様ひずみと定 義する。最高荷重点において次式が成立する。

$$
\frac{\mathrm{d} \sigma}{\mathrm{d} \varepsilon}=\sigma
$$

(2)式と（4)式を組合せれば, 一様ひずみ $\varepsilon_{u}$ は次式のように 与えられる。

$$
\varepsilon_{u}=\frac{\mathrm{d} \ln \sigma}{\mathrm{d} \ln \varepsilon}=n^{\prime}=n+\bar{\gamma} m+A \delta
$$

$n^{\prime}$ は応力-ひずみ線図上の見かけの加工硬化率であり, 次式 で定義される $\bar{\gamma}$ と $\delta$ それぞれ変形中のひずみ速度と温度の ひずみに対する変化率を示す工程変数である。これらの工程 変数は, 意識的に実験中に変化させることのできるパラメー 夕であって，材料定数とは異なる意味を有するものである。

$$
\bar{\gamma}=\frac{\mathrm{d} \ln \dot{\varepsilon}}{\mathrm{d} \ln \varepsilon}, \quad \delta=\frac{\mathrm{d}(1 / T)}{\mathrm{d} \ln \varepsilon}
$$

これからの議論では, これらの工程変数文とは（6)式に従っ て記述され，引張変形中に一定值として算定できるものとす る。そうすると，(1)式は次式のように与えられることにな る。

$$
\sigma=\sigma(\varepsilon, \dot{\varepsilon}(\varepsilon), T(\varepsilon))
$$

（5）式は，(2)式に従う材料の一様ひずみは，材料定数だけで はなく，ひずみ速度と温度の変化率にも左右され，ひずみ速 度を加速するほど，また変形中に温度を低下させるほど大き くなることを示唆している。通常, 材料定数 $A$ は正の值と考 えられるからである。

(2)式を掛け算型と呼ぶなら，(8)式の構成方程式は足し算 型であり, このタイプもごく一般的に用いられる形式であ る。

$$
\sigma=K\left\{\varepsilon^{n}+m^{\prime} \ln \left(\frac{\dot{\varepsilon}}{\dot{\varepsilon}_{0}}\right)\right\} \exp \left(\frac{A}{T}\right)
$$

(2) 式中の 4 個の材料定数のうち $n, A$ の定義は同一であるが, 応力のひずみ速度依存性を表す $m^{\prime}$ は（9）式のように定義さ れ，(3)式中の $m$ とは異質である。さらに，它は任意の初期 ひずみ速度であり, $K$ は $\varepsilon=\dot{\varepsilon} / \dot{\varepsilon}_{0}=1$ かつ $T=\infty$ のきの応力值で ある。

$$
m^{\prime}=\frac{1}{K} \frac{\partial \sigma}{\partial \ln \dot{\varepsilon}}
$$

(2)式の不安定条件と（8)式の足し算型構成方程式の組合せ では，一様ひずみは解析的には得られず，（10)式の代数方程
式の実数根として与えられる。

$$
\varepsilon^{n}-(n+A \delta) \varepsilon^{n-1}+m^{\prime} \gamma \varepsilon-(1+A \delta) m^{\prime} \gamma=0
$$

ここでも一様ひずみの值は, 材料定数 $m^{\prime}, n, A$ に加えて, 工

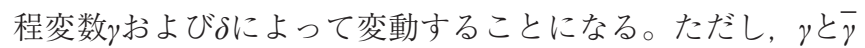
との間に次の関係がある。

$$
\bar{\gamma}=\frac{\mathrm{d} \ln \dot{\varepsilon}}{\mathrm{d} \ln \varepsilon}=\frac{\mathrm{d} \varepsilon}{\mathrm{d} \ln \varepsilon} \frac{\mathrm{d} \ln \dot{\varepsilon}}{\mathrm{d} \varepsilon}=\varepsilon \gamma
$$

(2)式と（8)式から派生する議論では, 応力, ひずみ, ひ ずみ速度, 温度の 4 パラメー夕を前提にすることになるが, Zener-HollomonのパラメータZ（(12)式）を導入すれば, 応 力, ひずみ, $Z$ の 3 変数間の議論に簡略化できる。 $(12)$ 式中 の定数 $B$ は (2)式の $A$ と $A=B m$ の関係があることに注意する。 この場合，（13）式を（4）式と組合せれば，（14）式によって一 様ひずみが与えられることになる。

$$
\begin{gathered}
Z=\dot{\varepsilon} \exp \left(\frac{B}{T}\right) \quad(A=B m) \\
\sigma=K Z^{m} \varepsilon^{n} \\
\varepsilon_{u}=n+\bar{\zeta} m=\frac{n}{1-\zeta m}
\end{gathered}
$$

ただし，工程変数ととらの定義と関係は

$$
\bar{\zeta}=\frac{\mathrm{d} \ln Z}{\mathrm{~d} \ln \varepsilon}=\frac{\mathrm{d} \varepsilon}{\mathrm{d} \ln \varepsilon} \frac{\mathrm{d} \ln Z}{\mathrm{~d} \varepsilon}=\varepsilon \zeta
$$

これまでの展開を要約すれば, 流動応力のひずみ依存性に加 えて, ひずみ速度と温度依存性をも考慮した構成方程式 (2), （8），(13) 式を不安定条件 (4) 式と組合せれば，いずれにせよ， 材料定数だけでなく，ひずみ速度と温度の変化率が一様ひず みに影響することが認識できる。変形中にひずみ速度を加速 するほど, 加工温度を低下させるほど一様ひずみの大きさが 増加することが予想される。一定温度下でのひずみ速度変 化率と局部ひずみとの対応については, すでに研究成果 ${ }^{9), 10)}$ があるので, ここでは, 温度の下降に伴う一様ひずみの増減 に関わる場合について検討を進める。

\section{3. 自然冷却の場合}

恒温槽内での引張試験は, 通常, 試験開始から破断時まで 一定の温度を維持して実施される。試験開始時に温度維持の 加熱制御を中止し, 恒温槽の扉を開け放し, 自然に試験片温 度が低下する状態で引張試験を行えば，降温プロセスの一様 ひずみに及ぼす影響を検討することができると考えた。

\section{1 供試板材}

板厚 $1 \mathrm{~mm}$ のSPZを用いた。これは，超塑性合金の中でも $523 \mathrm{~K}$ 付近で超塑性が最も顕著に発現することが知られる材 料で, 超塑性加工の変形解析や組織解析のモデル材として用 いられてきた。(3)式の $m$ 值は, 超塑性温度としては最も低

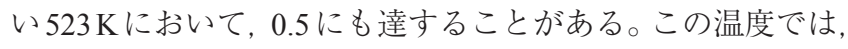
$n$ 值はほとんど計量できないほど小さく, 公称応力-ひずみ 線図はこれらの $m, n$ 值を反映して, 一様ひずみの量が極端 に小さく, 最高荷重点以降の擬一様変形が, 緩やかな荷重低 下を伴いながらだらだらと破断まで続く。さらに, 流動応力 の温度依存性の定量評価指数である $A$ の值（(3)式）も室温 


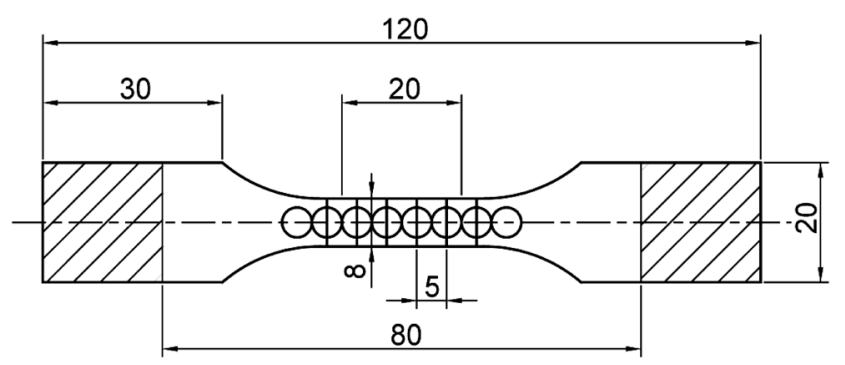

Fig. 1 Geometries of sheet specimen (SPZ).

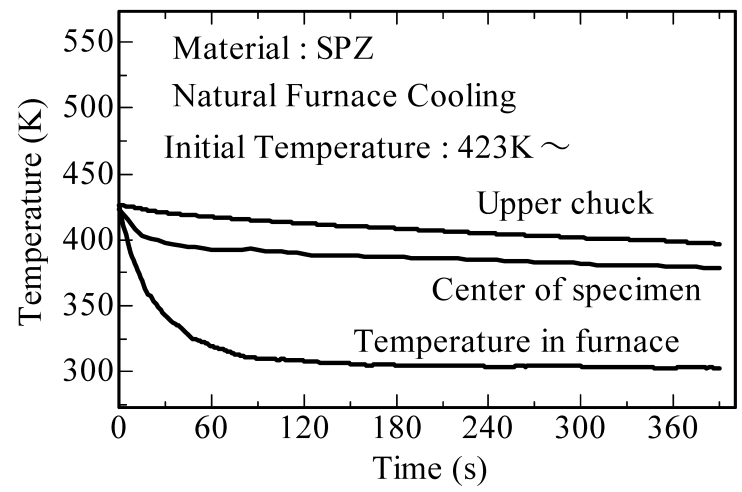

Fig. 2 Temperature descent at each part in natural cooling test.

と超塑性温度の間でそれなりに大きな值を示すものと考えら れる。降温プロセスの実験では最適なモデル材として使用で きる。試験片の幾何形状を Fig. 1に示す。試験片中央部には 直径 $5 \mathrm{~mm}$ のひずみ測定用円格子をスタンプした。自然冷却 における試験片中央部, 上部チャックおよび炉内の温度変化 をサーモグラフィにて計測した結果を Fig. 2に示す。試験片 中央部の温度変化は, 試験片平行部にて最も温度が低下した 点のデータを用いた。試験片中央部と上部チャックでは温度 差が存在するが，試験片の破断がすべて中央部で観測された ことから，試験片中央部の測定值を温度データとして用いる こととした。

\section{2 自然冷却の実験結果}

Fig. 3(a) には，423Kにおける公称応力ーひずみ線図，（b) には $423 \mathrm{~K}$ からの自然冷却における線図を示す。Fig. 3 (a) で は，クロスヘッドスピード（C.H.S.）の大きさに独立に大き な伸びが得られ，一様ひずみもほぼ変化していないことがわ かる。一方, Fig. 3(b) の自然冷却では, 総体的な全伸びの 低下が認められ，加えて，一様ひずみはC.H.S.が小さくなる につれて明瞭な右方向への移動が示されている。

自然冷却の場合，試験片中央部で計測した温度变化を（6） 式の $\delta$ で定量化した結果を Fig. 4に示す。算出された $\delta$ の值は 最も大きなものでも約 $1.45 \times 10^{-4}$, 低いものでは $10^{-7}$ のオー ダの值を取り，非常に小さな值である。C.H.S.に対する傾向

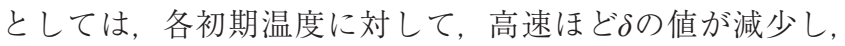
低速ほど值が大きいことがわかる。Fig. 5は, $\bar{\gamma} の$ 值を一定 温度の場合について計測した結果である。算出に用いるひ ずみ速度の值は，ひずみのデータを分割し，前後のひずみ の増加量とそれに要した時間を基に算出した。ここで求ま る值は，算出に使用した2つのひずみの中間のひずみに対す
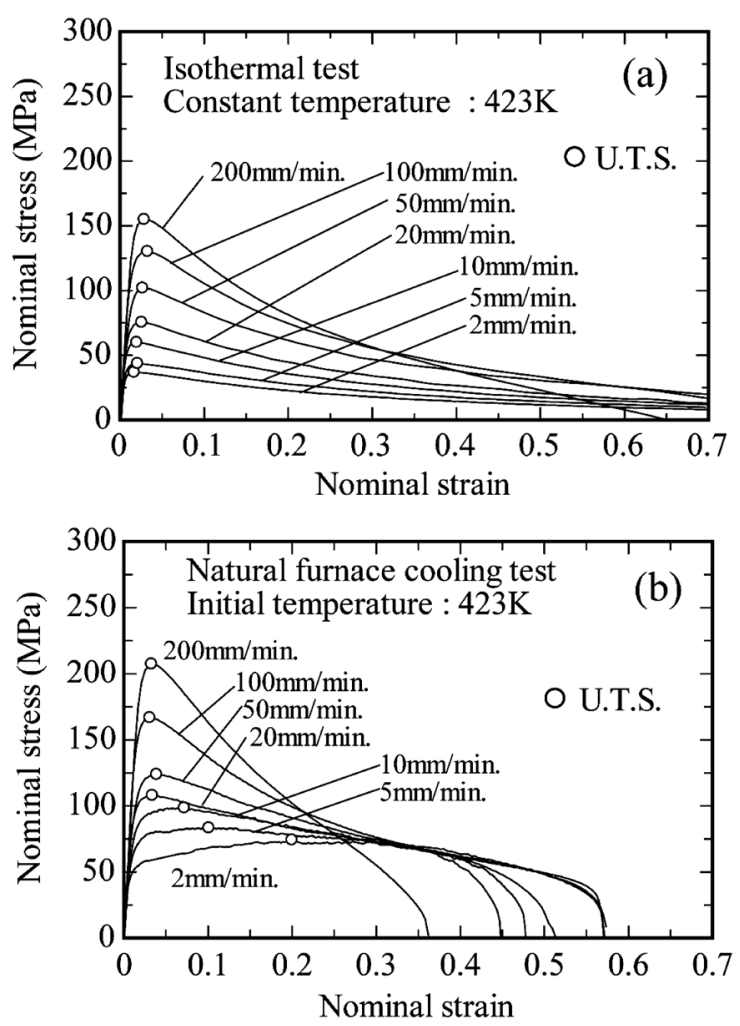

Fig. 3 Nominal stress vs. nominal strain curves at (a) constant testing temperature $423 \mathrm{~K}$ and (b) gradually decreasing temperature from $423 \mathrm{~K}$.

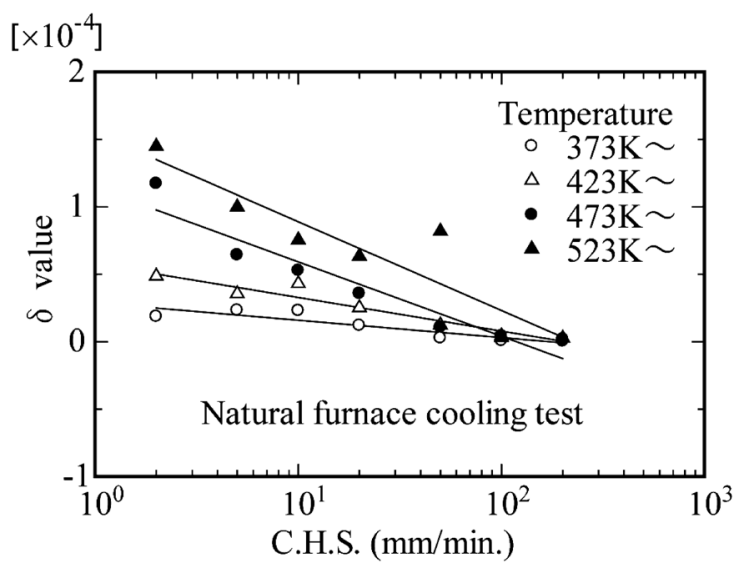

Fig. 4 Change of the $\delta$ values at natural furnace cooling test.

るひずみ速度となる。超塑性温度では, $\bar{\gamma}=0$ となり, 一定の C.H.S.に対して一定ひずみ速度試験になっていることがわか る。降温での值もほぼ同様な傾向を示した。

一定な各実験温度に対して,（16）式を適用し，重回帰計 算 $\left.{ }^{9)}, 10\right)$ によって材料定数 $m, n$ を算出する。重回帰計算とは, $\ln \sigma, \ln \varepsilon, \ln \dot{\varepsilon}$ を軸とする直交座標の空間で, データを平面と して近似することをいう。同じ実験データを使用し（2）式 を想定して重回帰計算によって材料定数 $m, n, A$ を算出する。 温度データが加わることで独立変数が 3 つなり可視化はで きないが, 重回帰計算することで超回帰平面が求まる。求 まった平面の傾きから材料定数を求める。それぞれの計算に より求めた材料定数を Fig. 6 (a)，(b) に示す。 


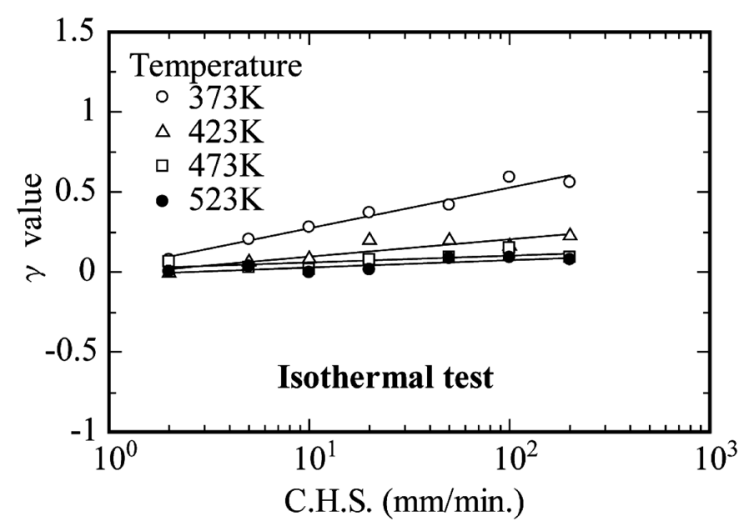

Fig. 5 Change of the $\gamma$ values.
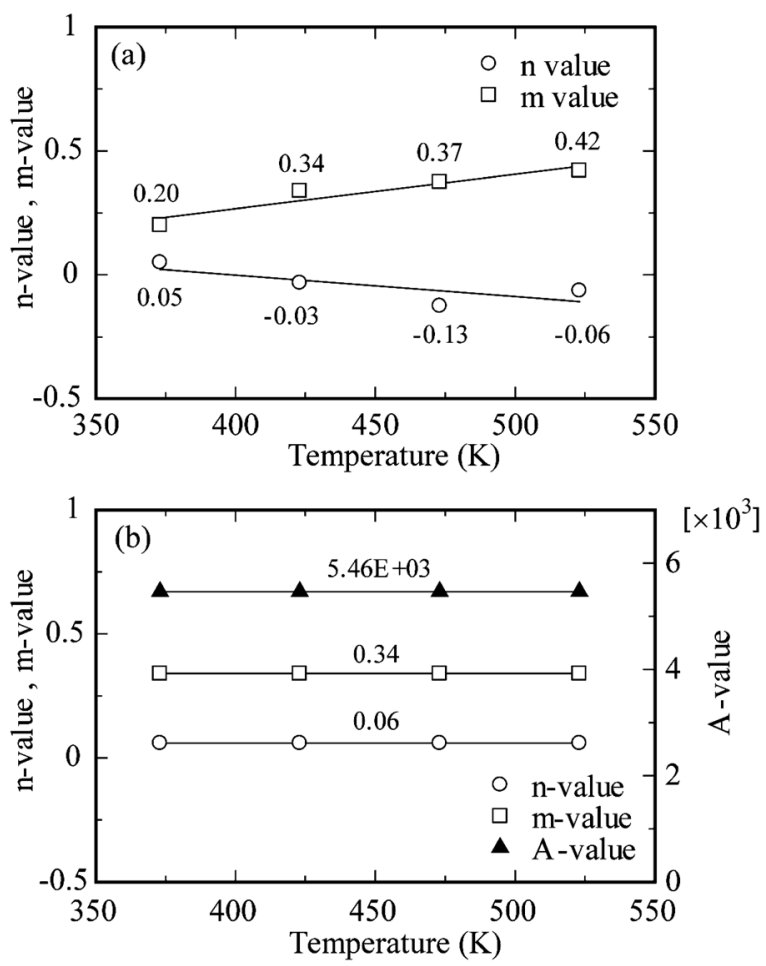

Fig. 6 Regression values of the material constants in (a) Eq. 16 and (b) Eq. 2.

$$
\sigma=K \dot{\varepsilon}^{m} \varepsilon^{n}
$$

Fig. 6（b）の值は，ほぼ一様と見なせるひずみ範囲，Fig. 3(a)，

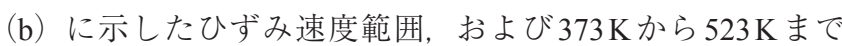
の温度範囲にわたる平均的な值と考えることができる。

Fig. 7(a) は, Fig. 6(b) の材料定数およびFig. 4, Fig. 5の $\delta$

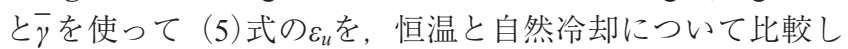
たものである。Fig. 7(b) には実験により得られた一様ひず みを示したが，恒温と自然冷却についての変化が比較でき る。一定温度においては, C.H.S.の増加に従って一様ひずみ は増加する傾向を示し，降温過程においては，低速域におけ る一様ひずみが大きく増加することが解析的にも実験的にも 緻密に説明されていることがわかる。

\section{4. 強制空気冷却の場合}

引張試験中の温度低下を定量的に示す工程変数 $\delta$ は, 引張
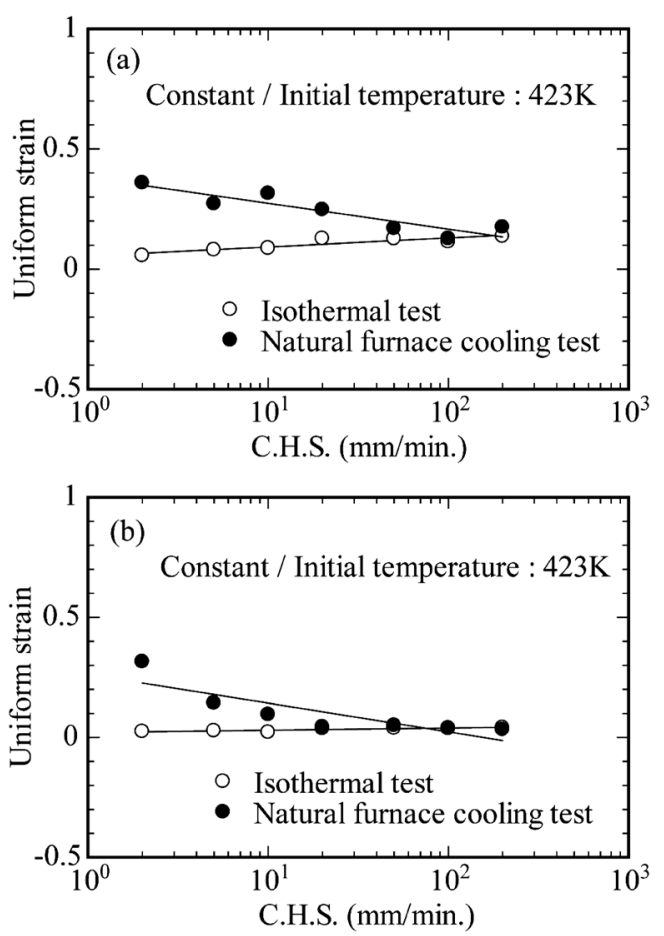

Fig. 7 Comparison of the uniform strain in isothermal test and natural furnace cooling test ((a) Calculated values. (b) Experimental results).

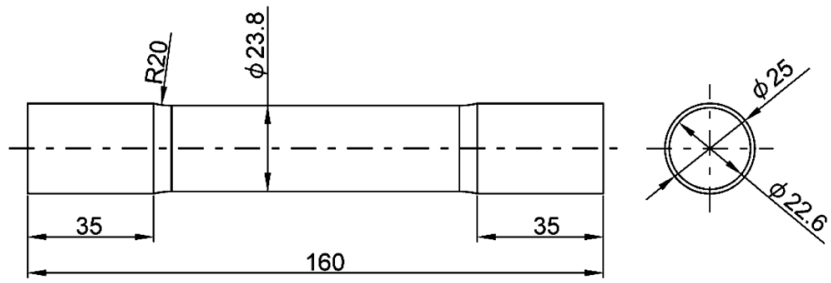

Fig. 8 Geometries of tube specimen (AZ31).

開始からの経過時間ではなく，ひずみに対して定義されてい るので, 自然冷却において, 炉内の試験片温度低下は時間に 対して一定と思われるが，ひずみに対してはC.H.S.の大きさ によって異なる值をとる。したがって, 自然冷却では高速に おいて $\delta$ 大きな值をとることができず, 一様ひずみもその ことを反映して, 高速において降温の効果が顕著に認められ ない。高速においても，降温の効果を明確に示すためには， 強制的な降温過程を導入して検討することが必要となる。そ こで，試験片に強制的に空気を当て，高い $\delta$ の值を得られる 状況で試験を実施する。冷却方法に関しては, 急激な温度低 下を与えるとともに試験片内の温度のばらつきを最小限に抑 えることが要求される。上記の問題を解決すべく, 試験片に パイプを用い, 内部へ空気を流入させることで冷却を行い降 温プロセスの影響を調査した。

\section{1 供試材}

供試材には, AZ31 合金を用いた。試験片形状を Fig. 8に 示す。試験片表面には， $2.5 \mathrm{~mm}$ 間隔でひずみ測定用にけが き線を入れた。Fig.9に試験片内部の空気の流れを示す。コ ンプレッサからの空気がマンドレルの中心から流入し, 試験 片を冷却し，マンドレルの周囲に設けられた溝から外部へ流 出する構造となっている。空気の流量は試験開始から破断に 


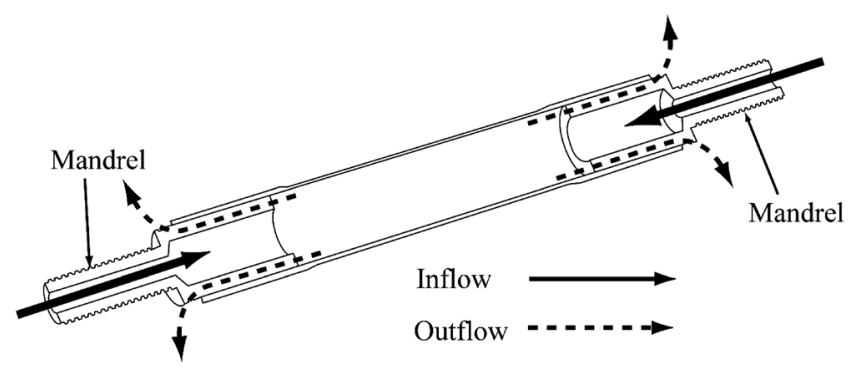

Fig. 9 Air flow in the tube.

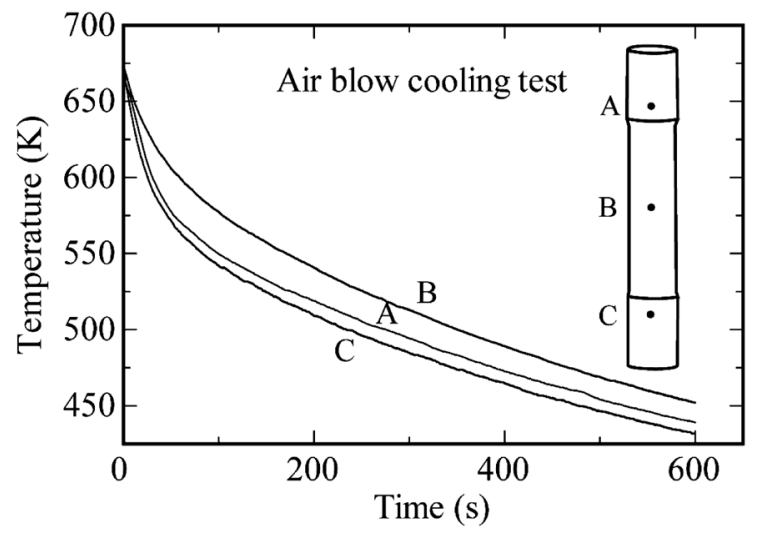

Fig. 10 Temperature descent at each part in air blow cooling test.

至るまで一定とし，その流量は約 $240 \mathrm{~L} / \mathrm{min}$ である。複数回 の測定により，温度低下速度の再現性は良好であることを確 認した。強制空気冷却による試験片の温度変化を Fig. 10に 示す。温度測定は図中に示した 3 点を測定点とし，熱電対に て測定した。自然冷却に比べ急速な温度低下を得られた。さ らに試験片内の温度のばらつきも抑えられている。 $\delta$ の算出 には，試験片中央部で測定した温度データを用いた。冷却方 法および試験材料が自然冷却の場合と異なるが，本研究では 同一材料かつ同一の冷却方法における降温プロセスと一定温 度の実験結果の比較に焦点を絞り，一様ひずみに与える影響 について検証を行う。それぞれの冷却方法による実験結果を 独立して評価することで材料特性值の差異による影響を議論 することは不要となる。さらに異種材料での実験を通じて, 降温プロセスが一様伸び増加の普遍的な手法であることを示 す。

\section{2 強制空気冷却の実験結果}

Fig. 11 (a) には，673Kにおける公称応力ーひずみ線図, Fig. 11 (b) には，673Kからの強制空気冷却における線図を 示す。Fig. 11 (a) では, C.H.S.が大きくなるにつれ，一様ひ ずみが増加していることがわかる。これは, C.H.S.の増加 に従い，ひずみ速度変化率が増加しているためである。一 方，Fig. 11（b）の強制空気冷却では，自然冷却の場合と同様 に全伸びの低下が認められるが，一様ひずみは，すべての C.H.S.において定常試験の結果よりも増加していることがわ かる。

$\delta の$ C.H.S. に対する変化を Fig. 12に示す。自然冷却の場合 と同様, 高速では值が小さくなっている。ひずみ速度変化率 については，一定温度での試験と同様にC.H.S.の増加に従い

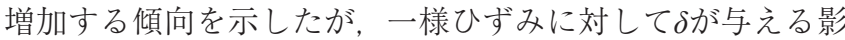
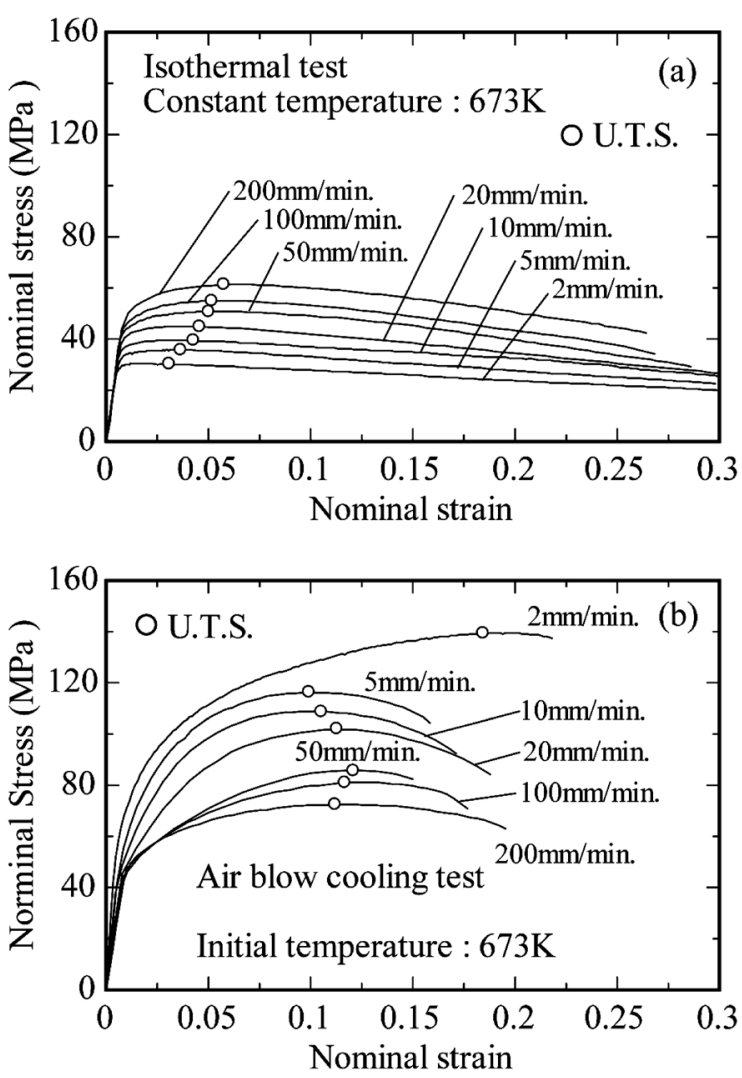

Fig. 11 Nominal stress vs. nominal strain curves at (a) constant testing temperature $673 \mathrm{~K}$ and (b) gradually decreasing temperature from $673 \mathrm{~K}$.

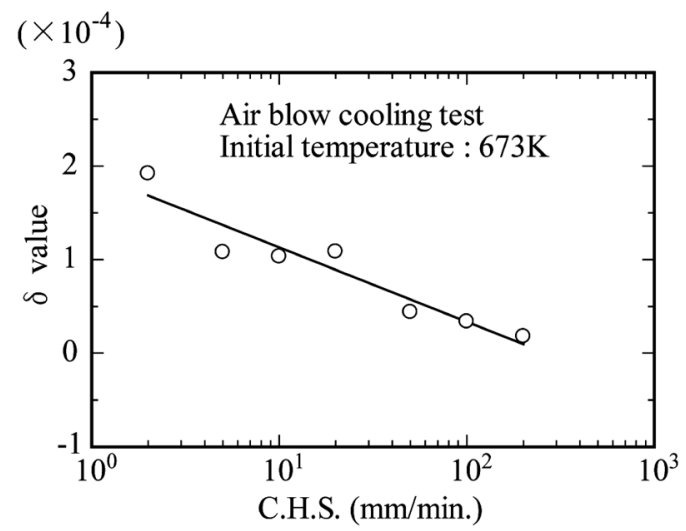

Fig. 12 Change of the $\delta$ values at air blow cooling test.

響の方が大きいため, 低速での変形においてより大きなひず み量が得られたと考えられる。

\section{5. 材料定数の算定および理論値の算出}

強制空気冷却試験により得られたデー夕を基に算出した 各構成方程式における材料定数を Table 1に示す。これらの 值および工程変数を（5),(10)式に代入することで掛け算 型，足し算型の構成方程式による一様ひずみが理論值とし て求まる。どちらの構成方程式においても，Aは大きな值を とる。（5)，(10)式において，Aは $\delta$ と掛合せた形で記述され ており，変形中の温度変化が一様ひずみに及ぼす影響の大き さがわかる。強制空気冷却の実験結果より得られた $\delta$ は, 最 も高いもので $1.92 \times 10^{-4}$ (C.H.S.: $2 \mathrm{~mm} / \mathrm{min}$ ), 最も低いもの 
Table 1 Material constants in each constitutive equation.

\begin{tabular}{l|c|c|c|c}
\hline \hline & $n$ & $m$ & $A$ & $K$ \\
\hline Multiplication type & 0.032 & 0.101 & 1233 & 16.86 \\
\hline & $n$ & $m^{\prime}$ & $A$ & $K$ \\
\hline Addition type & 0.037 & 0.093 & 1047 & 8.96 \\
\hline
\end{tabular}

Measurement range: $\varepsilon: 0.05 \sim 0.09, \dot{\varepsilon}: 0.0524 \sim 0.1265\left[\mathrm{~s}^{-1}\right]$, $\left.T: 373 \sim 673[\mathrm{~K}], \dot{\dot{\varepsilon}_{0}}: 0.00001 \mathrm{~s}^{-1}\right]$.
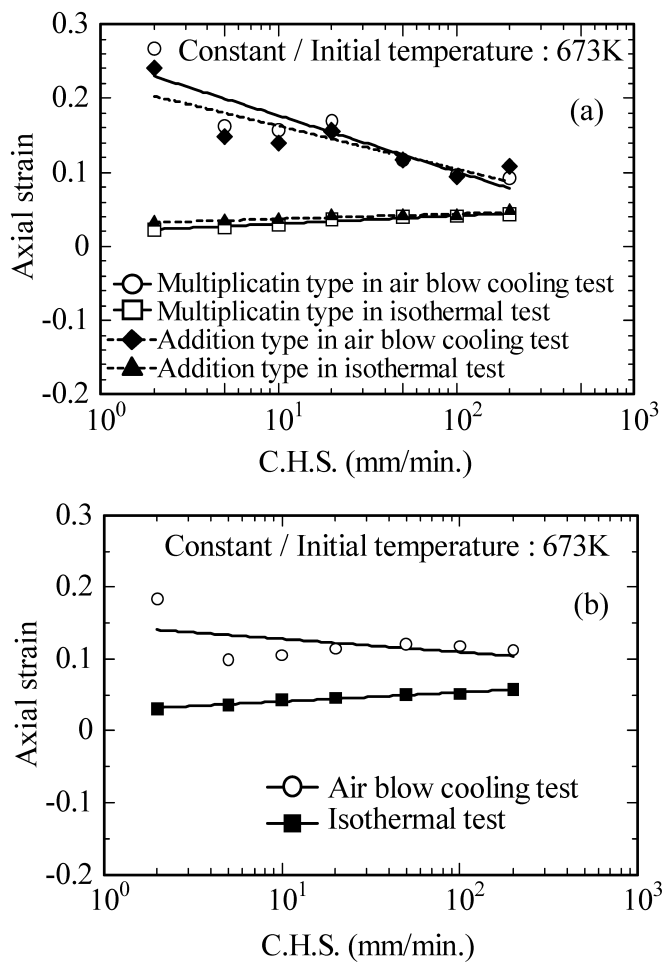

Fig. 13 Comparison of the uniform strain in isothermal test and air blow cooling test ((a) Calculated values, (b) Experimental results).

では $1.81 \times 10^{-5}$ (C.H.S.: $\left.200 \mathrm{~mm} / \mathrm{min}\right)$ と非常に小さい值であ るが，Aと掛合せることで工程中の温度変化の影響は劇的に 変わる。例えば，掛け算型構成方程式において，C.H.S.が $2 \mathrm{~mm} / \mathrm{min}$ のとき, 理論值の一様ひずみに占める $A \delta$ 項の割合 は，90\%近くになる。

Fig. 13 (a) は, Table 1に示した材料定数の值を用いて（5） 式および (10)式から算出される一様ひずみを恒温と強制空 気冷却について比較したものである。（5)式と（10)式では, 一様ひずみの定義のされ方は異なっているが, 同様の解析結 果が得られていることがわかる。Fig. 13（b）は，実験により 得られた一様ひずみである。実験值と理論值ともにすべての C.H.S.において, 降温過程の方が一様ひずみが増加するとい う傾向は同様であるが，その值には乘離がみられ，理論值の 方が大きく算出される結果となった。この原因として理論值 の計算において $\delta$ 変数としてではなく, 定数として扱って いることが考えられる。実際の試験においては, Fig. 10から もわかるように温度低下の割合は時間の経過とともに変化し ている。 $\delta$ 経過時間ではなく，ひずみに対して定義される

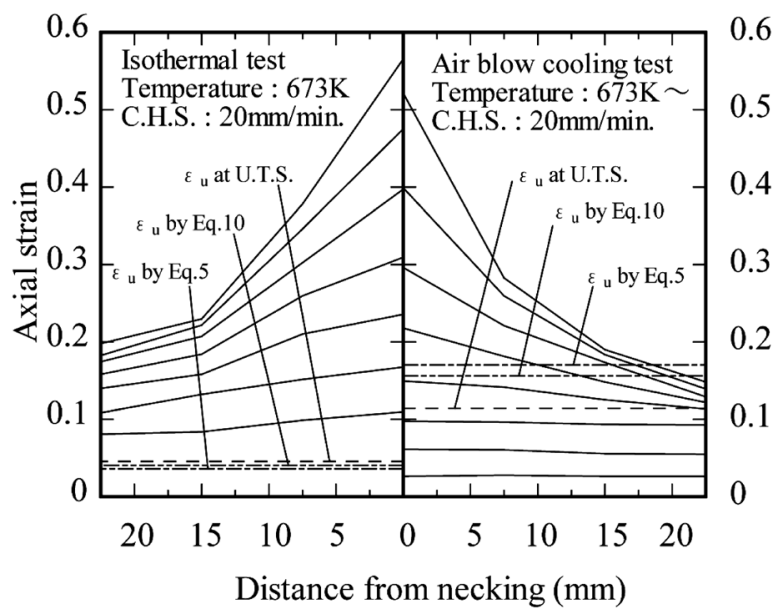

Fig. 14 Axial strain distribution (C.H.S.: $20 \mathrm{~mm} / \mathrm{min}$ ).

ものの, 試験中に刻々と変化し, 一定值ではない。C.H.S.が 低いほど靟離が大きいことはこれが原因であると考えられ る。また, 材料定数の算出に用いるひずみ, ひずみ速度, 温 度のデー夕範囲を変化させることで材料定数が変化すること も要因として挙げられる。(2),(8) 式を用いた材料定数の算 定法についての研究 ${ }^{11)}$ においても, デー夕範囲と材料定数 の変化について言及されている。温度変化を伴う変形に対す る材料定数の算定についての議論も実験と合せて検討してい く必要がある。

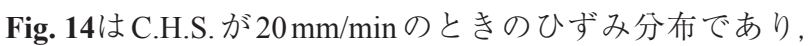
定常試験と降温試験を比較したものである。図中には，一様 ひずみの実験值および（5)，(10)式による理論值を併せて記 載した。定常試験では, 理論值が実験值と近似している。一 方, 降温試験においては, 理論值が実験值に対してかなり大 きく算出されており，その值は試験片が局所変形に至ってい る領域であることは明らかである。

\section{6. 結言}

これまで，ひずみ，ひずみ速度，温度を含む構成方程式を 利用した鉄鋼材料の熱間での変形抵抗に関する研究 ${ }^{8)}$ が行 われてきた。しかし, これらは一様ひずみについては議論さ れていない。本研究では, 一様ひずみの増加に関する温度依 存性について考察を行い, 変形中の温度低下が一様ひずみの 増加に寄与することを示した。温度低下が材料の成形性に与 える影響については, 全伸びの低下や全伸びに占める一様ひ ずみの割合の増加についての議論などを残すが, 今回は, 一 様ひずみに主眼を置いた。

自然冷却と強制空気冷却の実験では，おのおのの試験に対 して，降温プロセスと一定温度での試験結果を比較すること で, 変形中の温度低下が一様ひずみに与える影響を評価し た。自然冷却では, 低速での変形で一様ひずみの増加が観察 された。これは変形に時間を要したことで, 変形中の温度低 下が大きくなり，降温の影響をより大きく受けたためであ る。強制空気冷却のように急速な温度低下を与えることで, 高速での変形に対しても一様ひずみの増加が観察された。効 率のよい冷却方法および温度低下の割合を適切に制御するこ とで，更なる一様ひずみの増加が期待できる。

本研究で得られた結果は, 延性金属全般に対して適用可能 
である。また, 単軸引張試験を用いて実験・考察を行ったが, 一般プレス加工においても温度低下を伴う変形が安定な変形 能の向上に寄与するという予測は成立するものであり，今後 も使用量の増加が見込まれる非鉄軽量金属のプレス成形性の 改善策の1つであると考える。

\section{謝 辞}

本研究の実験とデー夕整理に協力された本大学院工学研究 科元院生 茂木 宽君 (現 富士重工業株式会社), 野口幸 起君（現 富士フィルム株式会社）にお礼申し上げます。

\section{参 考 文 献}

1) 松下富春：塑性と加工, 51 (2010), 165-166.

2) 深川 仁：日本機械学会誌, 115 (2012), 762-766.
3) 八代利之：軽金属, 62 (2012), 231.

4) B. B. Clow: Magnesium Technology 2002 (2002), 3-5.

5) 西野創一郎：軽金属, 61 (2011), 269-273.

6) 上村岳之, 吉水源宏, 大澤泰明：日本機械学会第 18 回機械材 料. 材料加工技術講演会 (M\&P2010) CD-ROM論文集，(2010）, 304.

7) T. Uemura, M. Yoshimizu and H. Ohsawa: Proc. ICAA12, (2010), 522-527.

8) 日本塑性加工学会編：塑性加工便覧, コロナ社, (2006), 1105-1107.

9) 吉澤宗晴, 大澤泰明：日本機械学会論文集 (A 編), 60 (1994), 1597-1603.

10）吉澤宗晴, 大澤泰明：日本機械学会論文集（A 編），62（1996）, $562-568$.

11) 宮武康, 大澤泰明：軽金属学会第 122 回春期大会講演概 要, (2012), 155-156. 